\title{
Increased intratumoral androgens in human breast carcinoma following aromatase inhibitor exemestane treatment
}

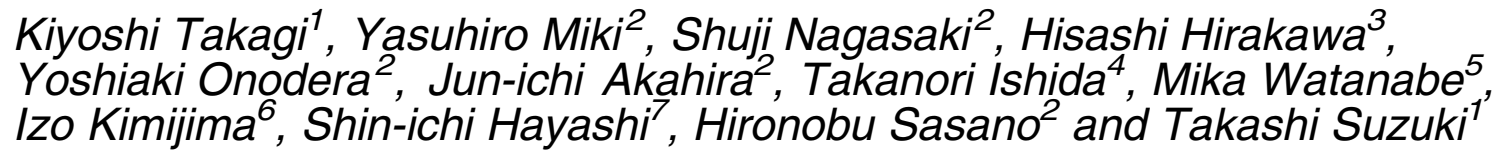

Departments of ${ }^{1}$ Pathology and Histotechnology and ${ }^{2}$ Anatomic Pathology, Tohoku University Graduate School of Medicine,

2-1 Seiryo-machi, Aoba-ku, Sendai, Miyagi-ken 980-8575, Japan

${ }^{3}$ Department of Surgery, Tohoku Kosai Hospital, Sendai, Japan

${ }^{4}$ Department of Surgical Oncology, Tohoku University Graduate School of Medicine, Sendai, Japan

${ }^{5}$ Department of Pathology, Tohoku University Hospital, Sendai, Japan

${ }^{6}$ Northern Fukushima Medical Center, Fukushima, Japan

${ }^{7}$ Department of Molecular and Functional Dynamics, Tohoku University Graduate School of Medicine, Sendai, Japan

(Correspondence should be addressed to T Suzuki; Email: t-suzuki@patholo2.med.tohoku.ac.jp)

\begin{abstract}
Sex steroids play important roles in the development of many human breast carcinomas, and aromatase inhibitors are used for the anti-estrogen therapy. Recent studies have demonstrated that aromatase suppressed $5 \alpha$-dihydrotestosterone (DHT) synthesis in breast carcinoma cells, but intratumoral concentration of androgens and its significance have not been reported in the breast carcinoma patients treated with aromatase inhibitors. Therefore, we examined androgen concentrations in breast carcinoma tissues treated with exemestane, and further performed in vitro studies to characterize the significance of androgen actions. Intratumoral DHT concentration was significantly higher in breast carcinoma tissues following exemestane treatment $(n=9)$ than those without the therapy $(n=7)$, and 17 $\beta$-hydroxysteroid dehydrogenase type 2 (17ßHSD2) status was significantly altered to be positive after the treatment. Following in vitro studies showed that $17 \beta \mathrm{HSD} 2$ expression was dose dependently induced by both DHT and exemestane in T-47D breast carcinoma cells, but these inductions were not additive. DHT-mediated induction of $17 \beta H S D 2$ expression was markedly suppressed by estradiol $\left(E_{2}\right)$ in T-47D cells. $E_{2}$-mediated cell proliferation was significantly inhibited by DHT in T-47D cells, associated with an increment of $17 \beta \mathrm{HSD} 2$ expression level. These findings suggest that intratumoral androgen actions are increased during exemestane treatment. $17 \beta \mathrm{HSD} 2$ is a potent DHT-induced gene in human breast carcinoma, and may not only be involved in anti-proliferative effects of DHT on breast carcinoma cells but also serve as a potential marker for response to aromatase inhibitor in the breast carcinoma patients.
\end{abstract}

Endocrine-Related Cancer (2010) 17 415-430

\section{Introduction}

Breast carcinoma is one of the most common malignancies in women worldwide. Sex steroids play very important roles in the development of estrogenresponsive breast carcinoma, and estrogens contribute immensely to the development of the breast carcinoma through binding with estrogen receptor (ER). Circulating estrogens are mainly secreted from the ovaries in premenopausal women, but a majority of breast carcinomas arise after menopause when ovaries ceased to be functional. Previous studies have demonstrated that biologically active estrogen, estradiol $\left(\mathrm{E}_{2}\right)$, was locally produced by estrogen-producing enzymes, such as aromatase (conversion from circulating androstenedione to estrone $\left(E_{1}\right)$ or testosterone to $E_{2}$; Silva et al. 1989), steroid sulfatase (STS; hydrolysis of circulating $\mathrm{E}_{1}$ sulfate to $\mathrm{E}_{1}$; Evans et al. 1994), and $17 \beta$-hydroxysteroid dehydrogenase type 1 (17ßHSD1; 
conversion from $\mathrm{E}_{1}$ to $\mathrm{E}_{2}$; Speirs et al. 1998) in the breast carcinoma.

An intratumoral concentration of bioactive androgen, $5 \alpha$-dihydrotestosterone (DHT), was also reported to be significantly higher in the breast carcinoma than in plasma (Mistry et al. 1986, Recchione et al. 1995, Suzuki et al. 2007), and androgen-producing enzymes, e.g. 17ßHSD5 (conversion from circulating androstenedione to testosterone) and $5 \alpha$-reductase type 1 ( $5 \alpha$ Red1; reduction of testosterone to DHT), were frequently expressed in the breast carcinoma (Suzuki et al. 2001). The potency of sex steroids is also regulated by sex steroid-metabolizing enzymes, such as estrogen sulfotransferase (EST; sulfonation of $E_{1}$ to $E_{1}$ sulfate) and $17 \beta \mathrm{HSD} 2$ (oxidation of $E_{2}$ to $E_{1}$ or testosterone to androstenedione; Adams et al. 1979, Suzuki et al. 2000). However, expression of the sex steroid-metabolizing enzymes was frequently decreased in the breast carcinoma tissues, resulting in an accumulation of intratumoral sex steroids (Suzuki et al. 2003).

Among these sex steroid-related enzymes, intratumoral aromatase has been established as an important target for the anti-estrogen therapy in the hormonedependent breast carcinoma in postmenopausal patients. Third-generation aromatase inhibitors are currently available, and these inhibitors are classified into two types: a steroidal aromatase inhibitor (e.g. exemestane), which interferes with the substrate-binding sites of aromatase as androgen analog; and non-steroidal aromatase inhibitors (e.g. anastrozole and letrozole), which block the electron transfer chain (Miller \& Dixon 2002). These aromatase inhibitors were all significantly associated with improved disease-free survival and good tolerability in breast carcinoma patients (Goss et al. 2003, Baum 2004, Coombes et al. 2004, Howell et al. 2005). In addition, neoadjuvant aromatase inhibitor therapy is frequently considered to improve surgical outcomes for the breast carcinoma patients (Olson et al. 2009).

Recently, Suzuki et al. (2007) have reported that DHT synthesis in aromatase-negative MCF-7 breast carcinoma cells was significantly inhibited by co-culture with aromatase-positive stromal cells isolated from human breast carcinoma tissue, which was also reversed by an addition of steroidal aromatase inhibitor exemestane. These findings suggest that aromatase inhibitor therapy may cause increased androgen actions with estrogen deprivation. However, to the best of our knowledge, intratumoral concentration of androgens and its significance have not been reported in the breast carcinoma with aromatase inhibitor treatment. Therefore, in this study, we first examined androgen concentrations in nine breast carcinoma tissues with exemestane treatment, and correlated these findings with immunohistochemical status of various sex steroid-related enzymes. These results demonstrated a strong association between exemestane treatment and intratumoral DHT concentration and 17 $\beta$ HSD2 status. Therefore, we subsequently performed in vitro studies to further characterize the significance of 17 $\beta \mathrm{HSD} 2$ in the breast carcinoma.

\section{Materials and methods}

\section{Patients and tissues}

Two sets of tissue specimens were used in this study. As a first set, nine specimens of ER-positive breast carcinoma were obtained from postmenopausal women who underwent surgical treatment from 2006 to 2007 in Tohoku Kosai Hospital, Sendai, Japan. All the patients received oral exemestane (Aromasin; Pfizer Japan Inc. (Tokyo, Japan)), $25 \mathrm{mg}$ daily for 2 weeks, before the surgery. The median age of these patients was 65 years (range 56-75). Specimens for steroid extraction were snap-frozen and stored at $-80{ }^{\circ} \mathrm{C}$ until use, and those for immunohistochemistry were fixed with $10 \%$ formalin and embedded in paraffin wax. In all cases, the corresponding core needle biopsy (CNB) specimens before the exemestane treatment were available in the formalin-fixed and paraffinembedded tissues.

As a second set, seven specimens of ER-positive breast carcinoma were also obtained from postmenopausal women who underwent surgical treatment from 2001 to 2002 in the Departments of Surgery at Tohoku University Hospital and in 2004 in the Tohoku Kosai Hospital, Sendai, Japan. These patients did not receive any neoadjuvant therapy including exemestane, and the median age was 57 years (range 50-69). Specimens for steroid extraction were snapfrozen, and those for immunohistochemistry were fixed with $10 \%$ formalin and embedded in paraffin wax. The clinicopathological characteristics of the breast carcinomas in these sets were summarized in Table 1. No statistical difference was detected in each parameter listed in Table 1, although these patient groups were treated at different periods of time (data not shown).

Research protocols for this study were approved by the ethics committee at Tohoku University School of Medicine and Tohoku Kosai Hospital. 
Table 1 Clinicopathological characteristics of breast carcinomas used in this study

\begin{tabular}{|c|c|c|}
\hline Value & $\begin{array}{l}\text { Breast carcinoma } \\
\text { treated with } \\
\text { exemestane } \\
\text { before surgery } \\
(n=9)\end{array}$ & $\begin{array}{c}\text { Breast carcinoma } \\
\text { without any } \\
\text { neoadjuvant } \\
\text { therapy }(n=7)\end{array}$ \\
\hline $\begin{array}{l}\text { Patient age } \\
\text { (years) }^{\mathrm{a}}\end{array}$ & $65(56-75)$ & $57(50-69)$ \\
\hline Tumor size $(\mathrm{mm})^{\mathrm{a}}$ & $20(10-35)$ & $26(10-50)$ \\
\hline \multicolumn{3}{|c|}{ Lymph node metastasis } \\
\hline Positive & 1 & 3 \\
\hline Negative & 8 & 4 \\
\hline \multicolumn{3}{|l|}{ Clinical stage } \\
\hline I & 5 & 2 \\
\hline II & 4 & 5 \\
\hline III & 0 & 0 \\
\hline \multicolumn{3}{|l|}{ Histological grade } \\
\hline 1 & 4 & 3 \\
\hline 2 & 3 & 2 \\
\hline 3 & 2 & 2 \\
\hline $\operatorname{ER~LI~(\% )~}{ }^{\mathrm{a}}$ & $72(14-85)$ & $81(10-96)$ \\
\hline PR LI (\%) ${ }^{a}$ & $39(0-76)$ & $52(8-75)$ \\
\hline AR LI (\%) ${ }^{a}$ & $50(24-82)$ & $35(8-53)$ \\
\hline \multicolumn{3}{|l|}{ HER2 status } \\
\hline Positive & 3 & 1 \\
\hline Negative & 5 & 6 \\
\hline
\end{tabular}

$E R$, estrogen receptor; PR, progesterone receptor; AR, androgen receptor; HER2, human epidermal growth factor 2; $\mathrm{LI}$, labeling index.

${ }^{a}$ Data are represented as median (min-max). Other values are presented as the number of cases.

\section{Liquid chromatography/electrospray tandem mass spectrometry}

Concentrations of $E_{2}$, DHT, testosterone, and androstenedione were measured by liquid chromatography/ electrospray tandem mass spectrometry (LC-MS/MS) analysis (ASKA Pharma Medical Co., Ltd, Kawasaki, Japan), as described previously (Miki et al. 2007, Suzuki et al. 2007, Yamashita et al. 2007, Shibuya et al. 2008). Briefly, breast carcinoma specimens ( $\sim 100 \mathrm{mg}$ for each sample) were homogenized in $1 \mathrm{ml}$ of distilled water, and steroids were extracted with diethyl ether from the homogenate after the addition of $100 \mathrm{pg}$ of $\mathrm{E}_{2^{-}}{ }^{13} \mathrm{C}_{4}$, DHT-d3, testosterone-d3, and androstenedione-d7 as internal standard.

In this study, we used an LC (Agilent 1100, Agilent Technologies, Waldbronn, Germany) coupled with an API 4000 triple-stage quadrupole mass spectrometer (Applied Biosystems, Mississauga, Ontario, Canada) operated with electron spray ionization in the positive ion mode, and the chromatographic separation was performed on Cadenza CD-C18 column $(3 \times 150 \mathrm{~mm}$, $3.5 \mathrm{~mm}$, Imtakt, Kyoto, Japan). The lower limit of quantification was $0.5 \mathrm{pg}$ for $\mathrm{E}_{2}, 0.5 \mathrm{pg}$ for DHT, $1 \mathrm{pg}$ for testosterone, and $1 \mathrm{pg}$ for androstenedione in this study.

\section{Immunohistochemistry}

The characteristics of primary antibodies for aromatase (Miki et al. 2007), STS (Suzuki et al. 2003), 17ßHSD5 (Penning et al. 2006), 5 $\alpha$ Red1 (Suzuki et al. 2001), and EST (Suzuki et al. 2003) were described previously. Rabbit monoclonal antibody for 17ßHSD1 (EP1682Y) and rabbit polyclonal antibody for 17ßHSD2 (10978-1-AP) were purchased from Epitomics Inc. (Burlingame, CA, USA) and Proteintech Group Inc. (Chicago, IL, USA) respectively. Monoclonal antibodies for ER (ER1D5), progesterone receptor (PR; MAB429), androgen receptor (AR; AR441), and Ki-67 (MIB1) were purchased from Immunotech (Marseille, France), Chemicon (Temecula, CA, USA), and DAKO (Carpinteria, CA, USA) respectively. Rabbit polyclonal antibody for human epidermal growth factor 2 (HER2; A0485) was obtained from DAKO.

A Histofine Kit (Nichirei, Tokyo, Japan), which employs the streptavidin-biotin amplification method, was used for immunohistochemistry in our study. The antigen-antibody complex was visualized with 3,3'-diaminobenzidine (DAB) solution (1 mM DAB, $50 \mathrm{mM}$ Tris- $\mathrm{HCl}$ buffer ( $\mathrm{pH}$ 7.6), and $0.006 \% \mathrm{H}_{2} \mathrm{O}_{2}$ ) and counterstained with hematoxylin.

Immunoreactivity of sex steroid-related enzymes was detected in the cytoplasm, and cases that had more than $10 \%$ of positive carcinoma cells were considered positive (Suzuki et al. 2007). Immunoreactivity of ER, PR, AR, and Ki-67 was detected in the nucleus. These immunoreactivities were evaluated in more than 1000 carcinoma cells for each case, and subsequently the percentage of immunoreactivity, i.e. labeling index (LI), was determined (Suzuki et al. 2007). Cases with ER LI, PR LI, or AR LI of more than $10 \%$ were considered ER-, PR-, or AR-positive breast carcinoma, according to a report by Allred et al. (1998). HER2 immunoreactivity was evaluated according to a grading system proposed in HercepTest (DAKO), and moderately or strongly circumscribed membrane staining of HER2 in more than $10 \%$ carcinoma cells was considered positive.

\section{Cell line and chemicals}

T-47D human breast carcinoma cell line was provided from the Cell Resource Center for Biomedical Research, Tohoku University (Sendai, Japan), and cultured in RPMI-1640 (Sigma-Aldrich) with 10\% fetal bovine serum (FBS; JRH Biosciences, Lenexa, KS, USA). T-47D cells were cultured with phenol redfree RPMI-1640 medium containing 10\% dextrancoated charcoal (DCC)-FBS for 3 days before treatment in the experiment. DHT, $\mathrm{E}_{2}$, and an AR 
antagonist hydroxyflutamide were purchased from Wako Pure Chemical Industries (Osaka, Japan), Wako Pure Chemical Industries, and Toronto Research Chemicals (Downsview, Ontario, Canada) respectively. Exemestane was kindly provided from Pfizer Japan Inc.

\section{Real-time PCR}

Total RNA was extracted using TRIzol reagent (Invitrogen Life Technologies Inc.), and cDNA was synthesized using a QuantiTect reverse transcription kit (Qiagen). Real-time PCR was carried out using the LightCycler System and FastStart DNA Master SYBR Green I (Roche Diagnostics). The PCR primer sequence of $17 \beta \mathrm{HSD} 2,5 \alpha \operatorname{Red} 1$, and the ribosomal protein L13A (RPL13A) used in this study was as follows. 17ßHSD2 (NM_002153): forward 5'-CAAAGGGAGGCTGGTGAA-3' and reverse 5'-TTGAGGACCTCTGTGTATTT-3'; 5 $\alpha$ Red1 (NM_001047): forward $5^{\prime}$-TGGGAGGAGGAAAGCCTATG- $3^{\prime}$ and reverse 5'-GCCACACCACTCCATGATTTC-3'; and RPL13A (NM_012423): forward 5'-CCTGGAGGAGAAGAGGAAAGAGA- ${ }^{\prime}$ and reverse $5^{\prime}$-TTGAGGACCTCTGTGTATTTGTCAA- $3^{\prime}$. PCR products were purified and subjected to direct sequencing in order to verify amplification of the correct sequences. 17RHSD2 and $5 \alpha$ Red 1 mRNA levels were summarized as the ratio of RPL13A mRNA level (\%).

\section{Immunoblotting}

The cell protein was extracted using M-PER Mammalian Protein Extraction Reagent (Pierce Biotechnology, Rockford, IL, USA) with Halt Protease Inhibitor Cocktail (Pierce Biotechnology). Twenty micrograms of the protein (whole cell extracts) were subjected to SDSPAGE (10\% acrylamide gel). Following SDS-PAGE, proteins were transferred onto Hybond $\mathrm{P}$ polyvinylidene difluoride membrane (GE Healthcare, Buckinghamshire, UK). The primary antibodies used in this study were 17ßHSD2 (10978-1-AP; Proteintech Group, Inc.) and $\beta$-actin (AC-15; Sigma-Aldrich). Antibody-protein complexes on the blots were detected using ECL Plus western blotting detection reagents (GE Healthcare), and the protein bands were visualized with LAS-1000 image analyzer (Fuji Photo Film Co., Tokyo, Japan).

\section{Microarray analysis}

Whole Human Genome Oligo Microarray (G4112F, ID 012391, Agilent Technologies), containing 41000 unique probes, was used in this study. Total RNA was extracted from T-47D cells after the treatment of DHT (10 nM), exemestane (100 nM), $\mathrm{E}_{2}(10 \mathrm{nM})$, or non-treatment for 3 days, and sample preparation and processing were done according to the manufacturer's protocol. The relative levels of gene expression were calculated by global normalization, and scatter plot analysis of the microarray data was performed using GeneSpring 10.0.2 (Agilent Technologies).

\section{Luciferase assay}

The luciferase assay was performed according to a previous report (Sakamoto et al. 2002) with some modifications. Briefly, we used androgen-responsive reporter plasmids pPSAE-Luc, which contained KLK3 androgen-responsive element (ARE; kindly provided from ASKA Pharmaceutical Co., Ltd), and estrogenresponsive reporter plasmids ptk-estrogen-responsive element (ERE)-Luc, containing Xenopus vitellogenin A2 ERE (Saji et al. 2001), in this study. One microgram of pPSAE-Luc plasmids or ptk-ERE-Luc plasmids and 200 ng pRL-TK control plasmids (Promega) were used to measure the transcriptional activity of endogenous AR or ER. Transient transfections were carried out using TransIT-LT Transfection Reagents (TaKaRa, Tokyo, Japan) in T-47D cells, and the luciferase activity of lysates was measured using a Dual-Luciferase Reporter Assay system (Promega) and Luminescencer-PSN (AB-2200; Atto Co., Tokyo, Japan) after incubation with the indicated concentrations of DHT and/or $\mathrm{E}_{2}$ for $24 \mathrm{~h}$. The transfection efficiency was normalized against Renilla luciferase activity using pRL-TK control plasmids, and the luciferase activity for each sample was evaluated as a ratio (\%) compared with that of controls.

\section{Cell proliferation assay}

T-47D cells were preincubated in phenol red-free RPMI-1640 medium containing 10\% DCC-FBS with or without DHT (10 $\mathrm{nM})$ for 3 days, and then seeded in 96-well plates (3000 cells/well). After the treatment with $E_{2}(100 \mathrm{pM})$ with or without DHT $(10 \mathrm{nM})$ for 3 days, the status of cell proliferation of T-47D cells was measured using a WST-8 (2-(2-methoxy-4nitrophenyl)-3-(4-nitrophenyl)-5-(2,4-disulfophenyl)2-H-tetrazolium, monosodium salt) method (Cell Counting Kit-8; Dojindo Inc., Kumamoto, Japan).

\section{Results}

\section{Intratumoral concentration of androgens in breast carcinoma tissues treated with exemestane}

We first examined tissue concentrations of sex steroids in breast carcinomas treated with exemestane using LC-MS/MS. Intratumoral $\mathrm{E}_{2}$ concentration was 


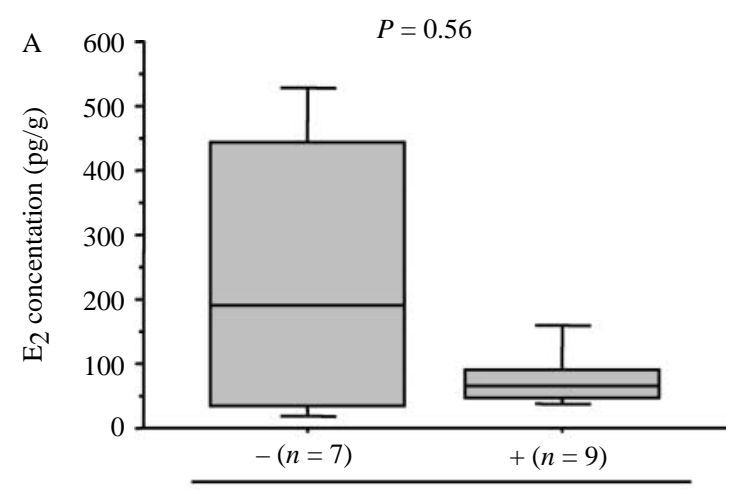

Exemestane treatment

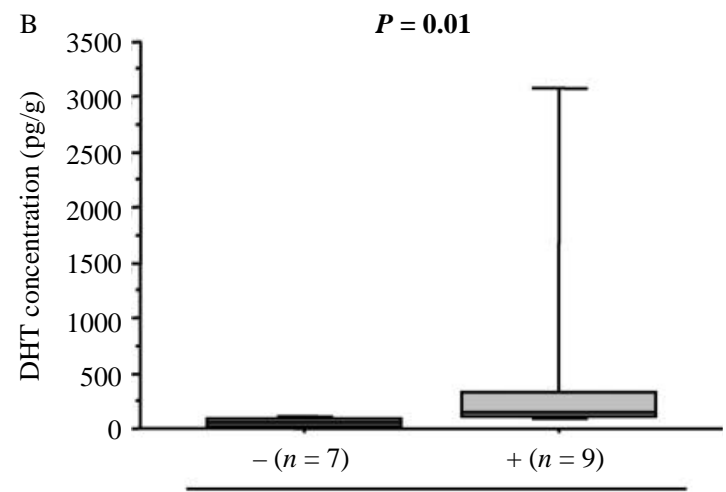

Exemestane treatment
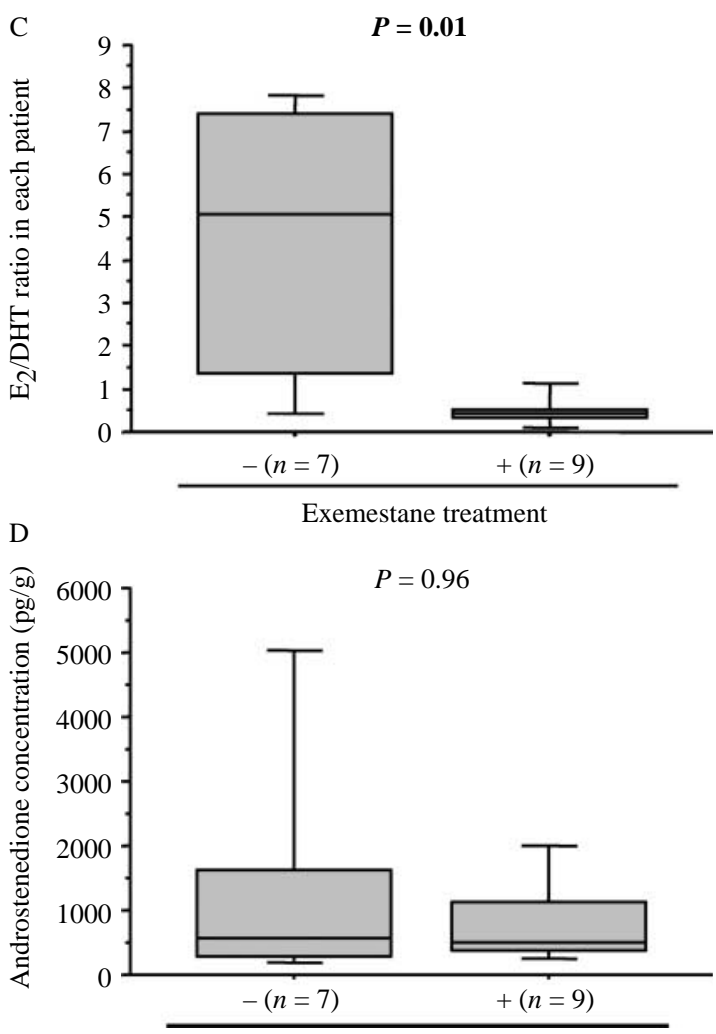

Exemestane treatment
0.35 -fold lower in the breast carcinoma tissues treated with exemestane (the median with min-max was 66 (33-176) $\mathrm{pg} / \mathrm{g}$ ) than those without the therapy (190 (16-534) $\mathrm{pg} / \mathrm{g}$ ), although $P$ value did not reach a significant level $(P=0.56$; Fig. 1A). On the other hand, intratumoral DHT concentration was significantly higher (2.3-fold and $P=0.01$ ) in the breast carcinomas treated with exemestane (145 (91-4987) pg/g) than those without exemestane therapy (64 (4.6-119) pg/g; Fig. 1B), and the corresponding $\mathrm{E}_{2}$ :DHT ratio in each patient was significantly $(0.08$-fold and $P=0.01)$ lower in a group of patients treated with exemestane therapy (Fig. 1C).

Intratumoral testosterone level was 1.4-fold higher in the group treated with exemestane (180 (110-427) $\mathrm{pg} / \mathrm{g})$ than that without exemestane treatment (133 (70-240) $\mathrm{pg} / \mathrm{g}$ ), although $P$ value did not reach a statistical significance $(P=0.10$; data not shown). Intratumoral concentration of androstenedione demonstrated similar levels $(P=0.96)$ regardless of the exemestane treatment (485 (153-2597) pg/g with exemestane and $561(160-5785) \mathrm{pg} / \mathrm{g}$ without exemestane; Fig. 1D).

Intratumoral concentration of DHT was significantly associated with that of testosterone in the breast carcinoma $(P=0.02, r=0.57)$, and DHT:testosterone ratio in each patient was similar regardless of the exemestane therapy ( $P=0.28$; data not shown).

\section{Immunolocalization of sex steroid-related enzymes in breast carcinoma tissues treated with exemestane}

We then examined an association between intratumoral concentration of $E_{2}$ and DHT and immunohistochemical status of sex steroid-related enzymes in nine breast carcinomas treated with exemestane. The immunoreactivity was detected in six cases $(67 \%)$ for aromatase, six cases $(67 \%)$ for STS, six cases $(67 \%)$ for $17 \beta \mathrm{HSD} 1$, five cases $(56 \%)$ for $17 \beta \mathrm{HSD} 5$, five cases $(56 \%)$ for $5 \alpha \operatorname{Red} 1$, six cases $(67 \%)$ for EST, and four cases (44\%) for 17ßHSD2 respectively. As shown in Table 2, intratumoral $\mathrm{E}_{2}$ concentration was inversely

Figure 1 Intratumoral concentrations of $E_{2}(A)$, DHT (B), and androstenedione $(D)$, and $E_{2}: D H T$ ratio in each patient $(C)$ in the breast carcinoma with or without exemestane treatment for 2 weeks using LC-MS/MS analysis. The median value is illustrated by a horizontal line in the box pot, and gray box denotes the 75th (upper margin) and 25th percentiles of the values (lower margin) respectively. The upper and lower bars indicate the 90th and 10th percentiles respectively. The statistical analyses were performed using a Mann-Whitney $U$ test. $P$ values $<0.05$ were considered significant, and are in bold. 
Table 2 Association between intratumoral concentration of sex steroids and the status of sex steroid-related enzymes in nine breast carcinomas with exemestane treatment

\begin{tabular}{|c|c|c|c|c|c|}
\hline Enzyme & $n$ & $\begin{array}{c}\mathbf{E}_{2} \text { concentration } \\
(\mathrm{pg} / \mathrm{g})\end{array}$ & $P$ value & $\begin{array}{c}\text { DHT concentration } \\
(\mathrm{pg} / \mathrm{g})\end{array}$ & $P$ value \\
\hline \multicolumn{6}{|c|}{ Estrogen-producing enzyme } \\
\hline Positive & 6 & $60(33-133)$ & & $167(91-4897)$ & \\
\hline Negative & 3 & $66(59-176)$ & 0.44 & $118(117-317)$ & 0.80 \\
\hline \multicolumn{6}{|l|}{ STS } \\
\hline Positive & 6 & $57(33-176)$ & & $117(91-4897)$ & \\
\hline Negative & 3 & $76(59-133)$ & 0.30 & $317(190-345)$ & 0.12 \\
\hline \multicolumn{6}{|l|}{$17 \beta$ HSD1 } \\
\hline Positive & 6 & $62(45-76)$ & & $167(109-897)$ & \\
\hline Negative & 3 & $133(33-176)$ & 0.44 & $117(91-345)$ & 0.44 \\
\hline \multicolumn{6}{|c|}{ Androgen-producing enzyme } \\
\hline Positive & 5 & $66(45-76)$ & & $118(109-4897)$ & \\
\hline Negative & 4 & $68(33-133)$ & $>0.99$ & $253(91-133)$ & 0.62 \\
\hline \multicolumn{6}{|l|}{$5 \alpha \operatorname{Red} 1$} \\
\hline Positive & 5 & $47(33-73)$ & & $145(91-4897)$ & \\
\hline Negative & 4 & $105(66-176)$ & 0.03 & $154(117-345)$ & 0.81 \\
\hline \multicolumn{6}{|c|}{ Sex steroid-metabolizing enzyme } \\
\hline \multicolumn{6}{|l|}{ EST } \\
\hline Positive & 6 & $75(33-176)$ & & $167(91-4897)$ & \\
\hline Negative & 3 & $59(45-66)$ & 0.30 & $118(109-317)$ & 0.61 \\
\hline \multicolumn{6}{|l|}{ 17ßHSD2 } \\
\hline Positive & 4 & $46(33-59)$ & & $213(91-4897)$ & \\
\hline Negative & 5 & $76(66-176)$ & 0.01 & $145(117-345)$ & 0.81 \\
\hline
\end{tabular}

Status of each sex steroid-related enzyme was evaluated by immunohistochemistry. Data are presented as the median with min-max. The statistical analyses were performed using a Mann-Whitney $U$ test. $P$ values $<0.05$ were considered significant, and described as boldface.

associated with the status of $5 \alpha \operatorname{Red} 1 \quad(P=0.03)$ and $17 \beta$ HSD2 immunoreactivity $(P=0.01)$, while no significant association was detected between intratumoral DHT concentration and any of sex steroid-related enzyme immunoreactivity status in our present study. All four cases positive for $17 \beta$ HSD2 were also positive for $5 \alpha$ Red1, and a significant positive association $(P=0.047)$ was detected between $17 \beta$ HSD 2 and $5 \alpha$ Red 1 status determined by immunohistochemistry.

We also evaluated an immunohistochemical status of these enzymes in the corresponding nine CNB specimens obtained before exemestane therapy. As shown in Table 3, 17ßHSD2 status became increased $(P=0.046)$ after the exemestane treatment (Fig. 2$)$, but no significant association was detected in the other six sex steroid-related enzymes examined in this study.

Ki-67 LI in carcinoma cells was significantly $(P=0.01)$ decreased after the exemestane therapy (19 (7-35) \% before the therapy and $10(2-23) \%$ after the therapy), as previously reported in exemestane (Miller \& Dixon 2002), anastrozole (Dowsett et al. 2005b), and letrozole (Ellis et al. 2003) neoadjuvant therapy treatment. PR LI was also significantly $(P=0.046)$ decreased after the exemestane therapy (39 (0-76) \% before the therapy and $20(0-67) \%$ after the therapy), as previously reported in the anastrozole treatment (Dowsett et al. 2005a). On the other hand, ER LI, AR LI, and HER2 status were not significantly different in each case between before and after the exemestane therapy in this study $(P=0.42, P=0.16$, and $P=0.56$ respectively).

\section{$17 \beta H S D 2$ as a DHT-induced gene in breast carcinoma cells}

In our LC-MS/MS analysis in human breast carcinoma tissues, intratumoral DHT concentration was significantly higher in the breast carcinoma treated with exemestane (Fig. 1B), and 17ßHSD2 status significantly increased after the treatment (Table 3). These results suggest an induction of $17 \beta \mathrm{HSD} 2$ by DHT and/or exemestane in the breast carcinoma cells, but such findings have not been reported yet to the best of 
Table 3 Association of sex steroid-related enzyme status in nine paired breast carcinoma tissues obtained before and after the exemestane treatment

\begin{tabular}{|c|c|c|c|}
\hline Enzyme & $\begin{array}{l}\text { Before the } \\
\text { treatment (CNB } \\
\text { specimens) }\end{array}$ & $\begin{array}{l}\text { After the } \\
\text { treatment } \\
\text { (surgical } \\
\text { specimens) }\end{array}$ & $P$ value \\
\hline \multicolumn{4}{|c|}{$\begin{array}{l}\text { Estrogen-producing enzyme } \\
\text { Aromatase }\end{array}$} \\
\hline Positive & 6 & 6 & \\
\hline Negative & 3 & 3 & $>0.99$ \\
\hline \multicolumn{4}{|l|}{ STS } \\
\hline Positive & 6 & 6 & \\
\hline Negative & 3 & 3 & 0.56 \\
\hline \multicolumn{4}{|l|}{$17 \beta \mathrm{HSD} 1$} \\
\hline Positive & 5 & 6 & \\
\hline Negative & 4 & 3 & $>0.99$ \\
\hline \multicolumn{4}{|c|}{ Androgen-producing enzyme } \\
\hline Positive & 3 & 5 & \\
\hline Negative & 6 & 4 & 0.16 \\
\hline \multicolumn{4}{|l|}{$5 \alpha \operatorname{Red} 1$} \\
\hline Positive & 5 & 5 & \\
\hline Negative & 4 & 4 & $>0.99$ \\
\hline \multicolumn{4}{|c|}{ Sex steroid-metabolizing enzyme } \\
\hline \multicolumn{4}{|l|}{ EST } \\
\hline Positive & 5 & 6 & \\
\hline Negative & 4 & 3 & 0.56 \\
\hline \multicolumn{4}{|l|}{$17 \beta \mathrm{HSD} 2$} \\
\hline Positive & 0 & 4 & \\
\hline Negative & 9 & 5 & 0.046 \\
\hline
\end{tabular}

Status of each steroid-related enzyme was evaluated by immunohistochemistry. Data are presented as the number of cases. The statistical analyses were performed using a Wilcoxon signed rank test. $P$ values $<0.05$ were considered significant, and described as boldface.

our knowledge. Therefore, we used T-47D breast carcinoma cells, which expressed both ER and AR, to further analyze this aspect (Migliaccio et al. 2000).

As shown in the upper panel of Fig. 3A, expression level of $17 \beta H S D 2$ mRNA was increased by DHT in a dose-dependent manner in T-47D cells, and this increment became significant from $100 \mathrm{pM}(P<0.001)$ compared to the basal level (non-treatment). DHT did not significantly change the $17 \beta H S D 2$ mRNA expression level when the cells were treated together with DHT and a potent AR antagonist hydroxyflutamide (Lee et al. 2002; $P=0.07$; Fig. 3A). Hydroxyflutamide alone did not significantly $(P=0.32)$ change the $17 \beta H S D 2$ mRNA level in T-47D cells (data not shown). DHT-mediated induction of 17 $\beta$ HSD2 expression was also confirmed at protein levels by immunoblotting in T-47D cells treated under the same condition (lower panels in Fig. 3A). Induction of
$17 \beta H S D 2$ mRNA expression by DHT occurred in a time-dependent manner, and when T-47D cells were treated with $10 \mathrm{nM}$ DHT, it became significant $(P=0.01)$ from $24 \mathrm{~h}$ after the treatment (data not shown). On the other hand, DHT treatment (10 nM for 3 days) did not significantly (1.0-fold and $P=0.83$ ) change the $5 \alpha$ Redl mRNA level in T-47D cells, although our immunohistochemical results showed a positive association between $5 \alpha \operatorname{Red} 1$ and 17ßHSD2 status in breast carcinomas treated with exemestane.

Exemestane also induced $17 \beta H S D 2$ mRNA expression in T-47D cells in a dose-dependent manner at a significant level from $1 \mathrm{nM}$ of exemestane $(P<0.05$ versus the non-treatment; Fig. 3B). Exemestane did not significantly alter the $17 \beta H S D 2$ mRNA expression level when the T-47D cells were treated together with hydroxyflutamide $(P=0.48)$. A similar tendency was confirmed at protein levels by immunoblotting (lower panels in Fig. 3B). However, 17ßHSD2
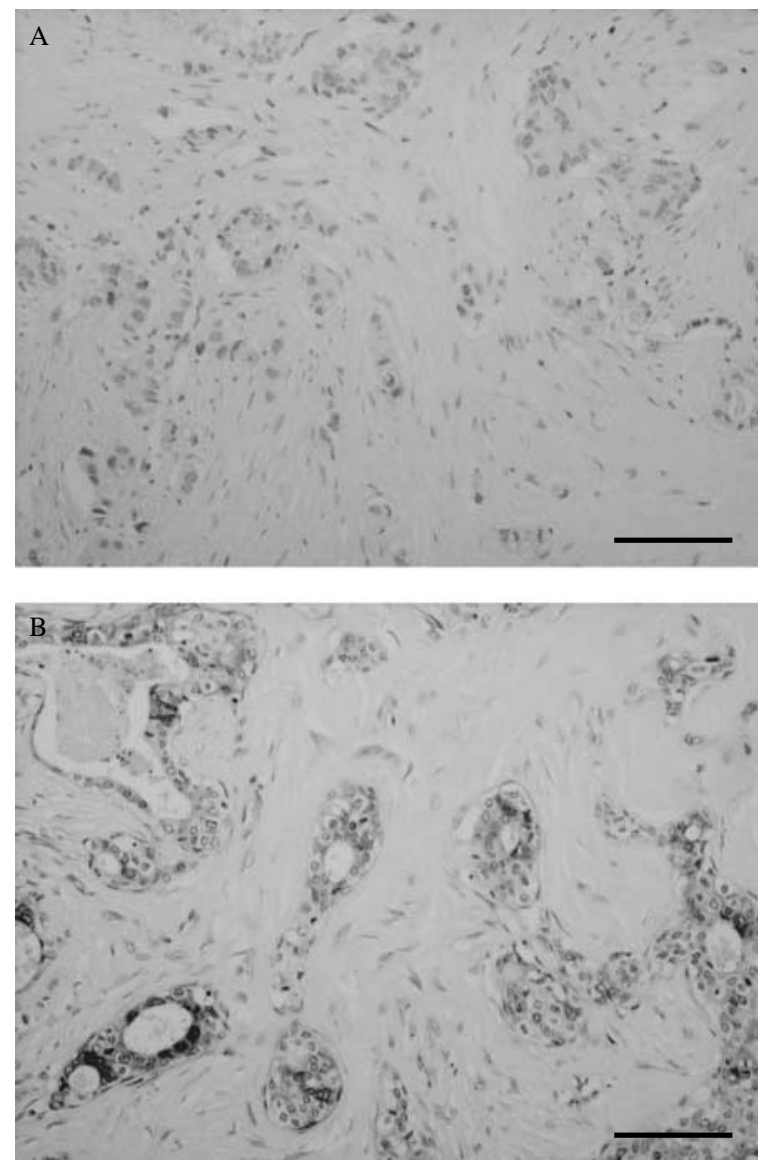

Figure 2 Immunohistochemistry for $17 \beta \mathrm{HSD} 2$ in the breast carcinoma tissue before $(A)$ and after $(B)$ the exemestane therapy in the same case. $17 \beta \mathrm{HSD} 2$ immunoreactivity was negative in $(A)$, but was detected in the cytoplasm of breast carcinoma cells in (B). Bar $=100 \mu \mathrm{m}$ respectively. 

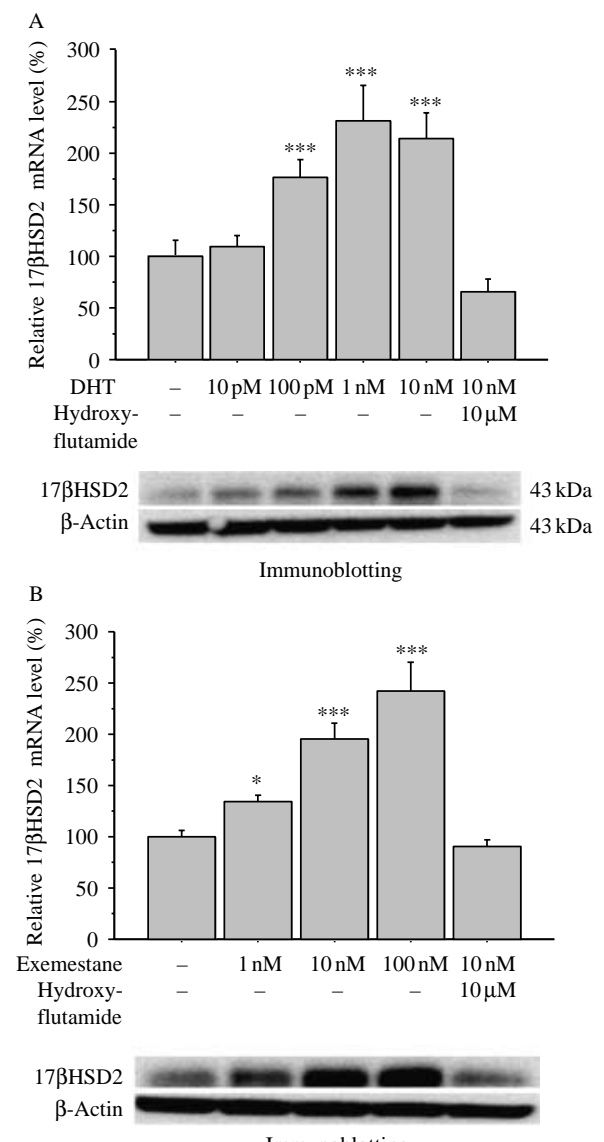

Immunoblotting
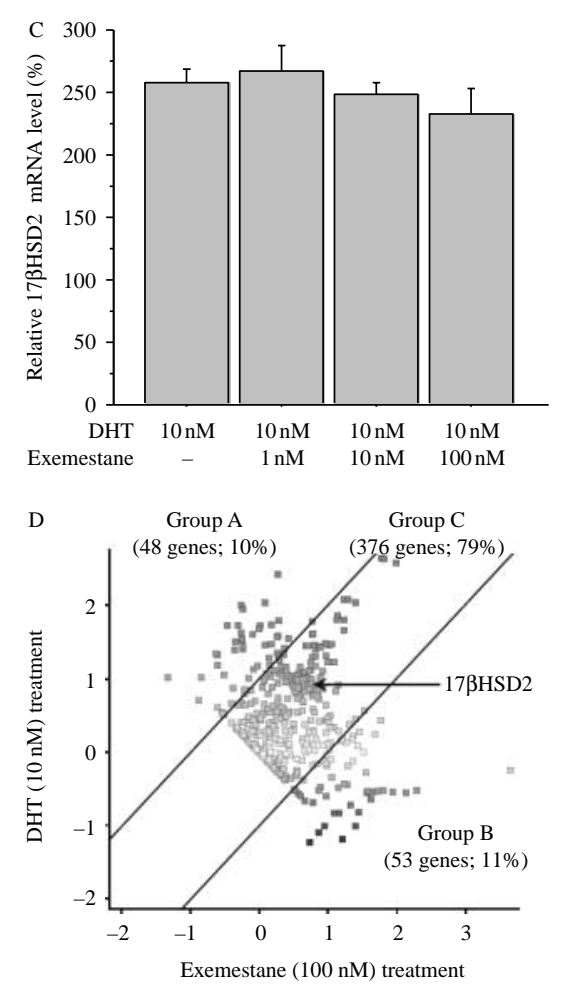

mRNA expression was not significantly (1.1-fold and $P=0.46)$ changed in T-47D cells treated with nonsteroidal aromatase inhibitor letrozole $(100 \mathrm{nM})$ for 3 days (data not shown). The exemestane-mediated induction of $17 \beta H S D 2$ mRNA was not detected in T-47D cells treated with $10 \mathrm{nM}$ DHT $(P=0.15$ between DHT $(10 \mathrm{nM})$ alone versus DHT $(10 \mathrm{nM})$ with exemestane (100 nM); Fig. 3C).

We further examined effects of DHT and exemestane on gene expressions in T-47D cells using microarray analysis. After the treatment with DHT $(10 \mathrm{nM})$ or exemestane $(100 \mathrm{nM})$ for 3 days, genes which demonstrated more than 2.5-fold increase compared to the basal level (non-treatment) were evaluated as 'an induced gene' in this study (Kannan et al. 2001). The number of DHT-induced genes identified was 337, while that of exemestane-induced genes was 308 (Table 4). Among these genes, 160 DHT-induced genes and 159 exemestane-induced genes were present in the gene ontology (GO) depth of 4 by FatiGO analysis (http://babelomics.bioinfo.cipf.es/EntryPoint ?loadForm=fatigo), and these were frequently associated with 'metabolic process' (Table 4). The number of genes induced by DHT and/or exemestane was 477 in total in this study, and we subsequently compared these gene expression profiles by a scatter plot. As shown in Fig. 3D, 48 genes $(10 \%)$ were predominantly (more than 2.0-fold) induced by DHT (group A), while 53

Figure 3 Induction of $17 \beta \mathrm{HSD} 2$ expression by DHT or exemestane in T-47D breast carcinoma cells. ( $A$ and $B$ ) Effects of DHT (A) or exemestane (B) on 17 $\beta$ HSD2 mRNA expression demonstrated by real-time PCR analysis. T-47D cells were treated with indicated concentrations of DHT (A) or exemestane (B) with or without an AR blocker hydroxyflutamide $(10 \mu \mathrm{M})$ for 3 days. $17 \beta H S D 2$ mRNA was evaluated as the ratio of $R P L 13 A$ mRNA level, and subsequently relative $17 \beta H S D 2$ mRNA level was summarized as a ratio (\%) compared with the basal level (non-treatment). Data are presented as mean \pm s.D. $(n=3)$. ${ }^{\star} P<0.05$ and ${ }^{\star \star \star} P<0.001$ versus non-treatment (left column). The statistical analyses were performed using a one-way ANOVA and Bonferroni test. The induction of 17 $\beta$ HSD2 expression was confirmed by immunoblotting under the same condition (lower panels). Immunoblotting for $\beta$-actin was performed as an internal standard of the experiment. (C) Effects of exemestane on DHT-mediated $17 \beta H S D 2$ mRNA by real-time PCR analysis. T-47D cells were treated with indicated concentrations of exemestane with DHT (10 nM) for 3 days. Relative $17 \beta H S D 2$ mRNA level was summarized as a ratio (\%) compared with the non-treatment. Data are presented as mean \pm S.D. $(n=3)$. (D) Scatter plot analysis of microarray data for the induced gene expression profile by DHT or exemestane. Four hundred and seventy-seven genes, those that were more than 2.5 -fold induced by DHT (10 nM) or exemestane $(100 \mathrm{nM})$ treatment for 3 days, were plotted on the logarithmic graph. Genes, those that were more than 2.0-fold higher in the DHT or exemestane treatment, were located outside of the diagonal line, and classified as group A or group B respectively. Genes $<2$.0-fold changes were plotted inside of these two lines, and classified as group $\mathrm{C}$. The location of $17 \beta H S D 2$ was marked in this figure. 
Table 4 Representative genes up-regulated by DHT or exemestane in T-47D cells and corresponding GO terms at level 4

\begin{tabular}{|c|c|c|c|c|c|}
\hline \multicolumn{3}{|c|}{ Induced by DHT } & \multicolumn{3}{|c|}{ Induced by exemestane } \\
\hline Fold & Common name & Gene symbol & Fold & Common name & Gene symbol \\
\hline \multicolumn{6}{|c|}{ (A) Representative genes up-regulated by DHT or exemestane in T-47D cells by microarray analysis } \\
\hline 24.4 & NM_023938 & C1orf116 & 16.5 & AK127378 & AK127378 \\
\hline 23.7 & BQ706262 & BQ706262 & 16.1 & NM_002776 & KLK10 \\
\hline 18.9 & NM_002776 & KLK10 & 15.5 & BQ706262 & BQ706262 \\
\hline 18.5 & NM_001185 & AZGP1 & 14.6 & NM_001185 & AZGP1 \\
\hline 16.6 & AK127378 & AK127378 & 13.5 & NM_023938 & C1orf116 \\
\hline 14.4 & NM_145000 & RANBP3L & 13.3 & DT220604 & DT220604 \\
\hline 12.4 & NM_199328 & CLDN8 & 12.0 & NM_005253 & FOSL2 \\
\hline 11.4 & DT220604 & DT220604 & 10.4 & NM_145000 & RANBP3L \\
\hline 11.2 & NM_006006 & ZBTB16 & 9.1 & NM_033226 & $\mathrm{ABCC} 12$ \\
\hline 10.7 & XR_017216 & LOC646282 & 9.1 & NM_001880 & ATF2 \\
\hline 10.4 & NM_004925 & AQP3 & 8.4 & NM_002867 & RAB3B \\
\hline 10.1 & NM_005627 & SGK & 7.6 & NM_199328 & CLDN8 \\
\hline 10.0 & NM_002867 & RAB3B & 7.3 & XR_017216 & LOC646282 \\
\hline 8.7 & NM_033226 & $\mathrm{ABCC} 12$ & 7.1 & NM_006006 & ZBTB16 \\
\hline 8.6 & NM_001880 & ATF2 & 6.7 & NM_012429 & SEC14L2 \\
\hline 8.2 & NM_024508 & BED2 & 6.6 & NM_144682 & SLFN13 \\
\hline 8.0 & NM_012429 & SEC14L2 & 6.2 & THC2688670 & THC2688670 \\
\hline 8.0 & NM_000063 & $\mathrm{C} 2$ & 6.2 & A_24_P558141 & A_24_P558141 \\
\hline 7.8 & BC0̄02830 & ATG3 & 6.0 & 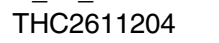 & THC̄ $\overline{6} 611204$ \\
\hline 7.8 & NM_013989 & DIO2 & 6.0 & NM_002153 & HSD17B2 \\
\hline 7.5 & NM_002272 & KRT4 & 5.9 & NM_004925 & AQP3 \\
\hline 6.8 & NM_144682 & SLFN13 & 5.8 & NM_005627 & SGK \\
\hline 6.7 & BC043381 & GJE1 & 5.7 & NM_003714 & STC2 \\
\hline 6.6 & NM_002153 & HSD17B2 & 5.5 & BC043381 & GJE1 \\
\hline 6.4 & NM_001030059 & PPAPDC1A & 5.4 & NM_002272 & KRT4 \\
\hline 6.2 & A_24_P290087 & A_24_P290087 & 5.4 & NM_024508 & ZBED2 \\
\hline 6.0 & NM_014141 & CNTNAP2 & 5.2 & THC2677796 & THC2677796 \\
\hline 5.9 & NM_024307 & GDPD3 & 5.2 & NM_014141 & CNTNAP2 \\
\hline 5.7 & NM_007253 & CYP4F8 & 5.1 & NM_198794 & MAP4K5 \\
\hline 5.5 & NM_005980 & S100P & 5.0 & BC039117 & ovos2 \\
\hline GO ID & & Term & & & ber of genes \\
\hline
\end{tabular}

(B) Representative GO terms at depth 4 in the DHT- or exemestane-induced genes

DHT-induced genes

GO:0007165
GO:0050794
GO:0043283
GO:0019538
GO:0044260
GO:0006810
GO:0019222
GO:0006139
GO:0048731
GO:0048518
Exemestane-induced genes
GO:0050794
GO:0043283
GO:0007165
GO:0019538
GO:0006810

Signal transduction

43

Regulation of cellular process $\quad 40$

Biopolymer metabolic process $\quad 40$

Protein metabolic process 32

Cellular macromolecule metabolic process 32

Transport $\quad 28$

Regulation of metabolic process $\quad 24$

Nucleobase, nucleoside, nucleotide, and 24

$\begin{array}{ll}\text { nucleic acid metabolic process } & \\ \text { System development } & 17\end{array}$

$\begin{array}{ll}\text { Positive regulation of biological process } & 16\end{array}$

Regulation of cellular process 40

Biopolymer metabolic process $\quad 39$

Signal transduction $\quad 35$

Protein metabolic process 32

$\begin{array}{ll}\text { Transport } & 32\end{array}$ 
Table 4 continued

\begin{tabular}{llc}
\hline GO ID & Term & Number of genes \\
\hline GO:0044260 & Cellular macromolecule metabolic process & 31 \\
GO:0019222 & Regulation of metabolic process & 25 \\
GO:0006139 & Nucleobase, nucleoside, nucleotide, and & 25 \\
& nucleic acid metabolic process & 25 \\
GO:0030154 & Cell differentiation & 21 \\
GO:0048731 & System development & \\
\hline
\end{tabular}

(A) Top 30 genes were listed according to the fold change in each group. Genes that were induced by both DHT and exemestane are in bold. (B) Depth of GO terms was classified by FatiGO analysis (http://babelomics.bioinfo.cipf.es/EntryPoint?loadForm=fatigo), and top ten GO terms at depth 4 are listed according to the number of genes belonged. The GO terms listed in both DHT- and exemestane-induced genes are in bold.

genes $(11 \%)$ were predominantly induced by exemestane (group B). However, a great majority (376 genes; $79 \%$ ) of the genes were induced by DHT or exemestane (group C) in a similar manner, and $17 \beta H S D 2$ was classified in this group.

\section{Suppression of 17ßHSD2 expression by $E_{2}$ in breast carcinoma cells}

We have demonstrated that expression of $17 \beta$ HSD2 was induced by DHT in the breast carcinoma cells. However, it is also true that $17 \beta \mathrm{HSD} 2$ expression was almost negligible in the breast carcinoma, although intratumoral DHT concentration was at a significant level (Recchione et al. 1995, Suzuki et al. 2000). In order to further explore these inconsistent findings, we examined effects of estrogens on 17 $\beta$ HSD2 expression in $\mathrm{T}-47 \mathrm{D}$ cells.

When T-47D cells were transiently transfected with pPSAE-Luc plasmids and treated with $10 \mathrm{nM}$ DHT, the luciferase activity of the cells was significantly (7.4-fold and $P<0.001$ ) increased compared to the basal level (non-treatment; Fig. 4A). $E_{2}$ inhibited ARE-dependent transactivation by DHT in a dosedependent manner, and the luciferase activities of T-47D cells treated with $10 \mathrm{nM}$ DHT and $10 \mathrm{nM} \mathrm{E}_{2}$ were significantly decreased to 0.35 -fold of that in cells treated with $10 \mathrm{nM}$ DHT alone $(P<0.001) . \mathrm{E}_{2}$ alone $(10 \mathrm{nM})$ did not significantly alter the luciferase activity $(P=0.58)$. DHT $(10 \mathrm{nM})$, however, did not significantly affect the ERE-dependent transactivation at both $10 \mathrm{pM}$ and $10 \mathrm{nM} \mathrm{E} \mathrm{E}_{2}$ treatment (Fig. 4B). DHT-mediated induction of $17 \beta H S D 2$ mRNA was significantly inhibited by $E_{2}$ in a dose-dependent manner (Fig. 4C). 17ßHSD2 mRNA level in T-47D cells treated with both $10 \mathrm{nM}$ DHT and $1 \mathrm{nM} \mathrm{E}_{2}$ was decreased to 0.25 -fold of that in cells treated with $10 \mathrm{nM}$ DHT alone $(P<0.001)$, and it was a similar level compared to the basal level (non-treatment with DHT; $P=0.32$; Fig. 4 C).
In the microarray analysis in T-47D cells, we identified 810 genes as $\mathrm{E}_{2}$-induced genes (treatment with $10 \mathrm{nM}$ of $\mathrm{E}_{2}$ for 3 days). The number of DHTand/or $E_{2}$-induced genes was 1029 in total. As shown in Fig. 4D, 144 genes (14\%) were predominantly induced by DHT (group D), 412 genes (40\%) were predominantly induced by $\mathrm{E}_{2}$ (group $\mathrm{E}$ ), and 473 genes $(46 \%)$ were induced by DHT or $\mathrm{E}_{2}$ in a similar manner (group F). The 144 genes in group D were all DHT-induced genes but not $\mathrm{E}_{2}$-induced genes, and $17 \beta \mathrm{HSD} 2$ was classified in this group.

When T-47D cells were treated with $\mathrm{E}_{2}(100 \mathrm{pM})$ for 3 days, the number of cells increased 1.4-fold in this study (Fig. 4E). The $\mathrm{E}_{2}$-mediated cell proliferation was significantly $(0.87$-fold and $P<0.05)$ inhibited by the addition of DHT $(10 \mathrm{nM})$, which was enhanced (0.76-fold and $P<0.01$ ) by pretreatment with DHT $(10 \mathrm{nM})$ for 3 days before the treatment with $E_{2}$ and DHT. However, under the same conditions of the experiment, expression level of $17 \beta H S D 2$ mRNA was significantly higher (1.7-fold and $P<0.001)$ following the treatment with $\mathrm{E}_{2}$ and DHT, and the highest (2.0-fold and $P<0.001$ ) by the pretreatment with DHT, compared to the cells treated with $\mathrm{E}_{2}$ alone. The cell proliferation activity was not significantly altered $(P=0.48)$ in T-47D cells between the treatment with DHT (10 nM) alone and non-treatment (data not shown).

\section{Discussion}

This is the first report to evaluate intratumoral androgen concentrations in the breast carcinoma treated with aromatase inhibitor. In our present study, intratumoral DHT concentrations were significantly (2.3-fold) higher in the breast carcinomas treated with exemestane than those not treated with exemestane (Fig. 1B). Our present results also demonstrated that $\mathrm{E}_{2}$ :DHT ratio in each patient was significantly (0.08-fold) lower in the breast carcinomas treated with exemestane than those with non-treated cases 


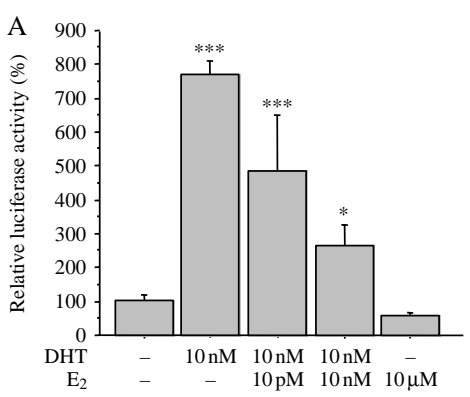

B

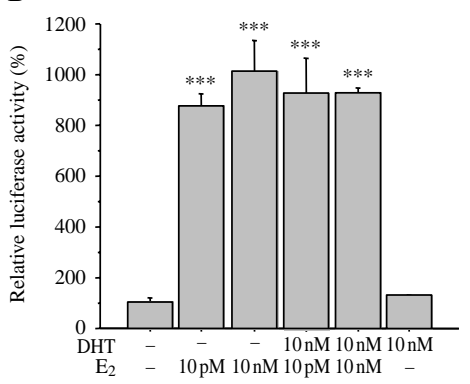

$\mathrm{C}$

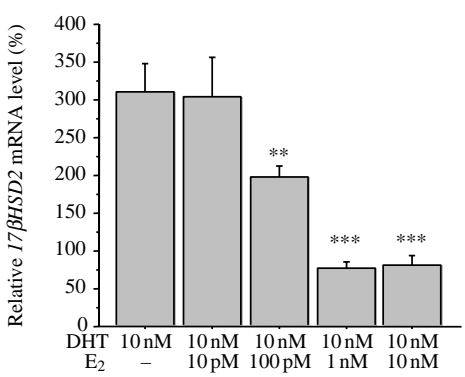

$\mathrm{D}$
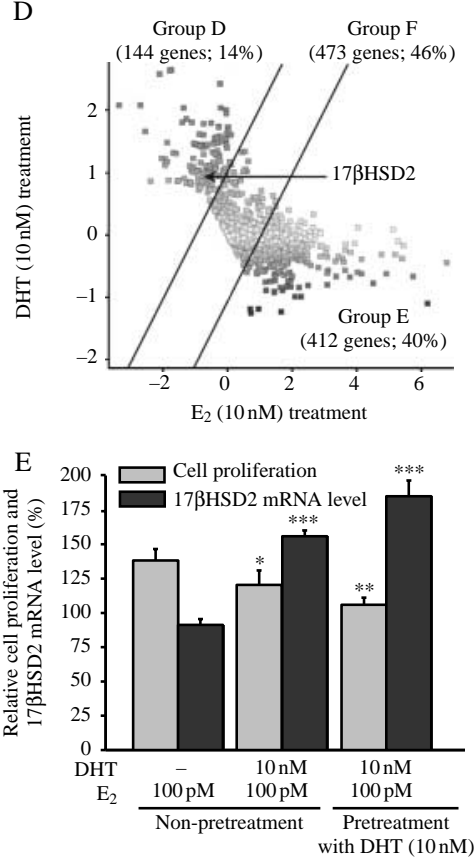

(Fig. 1C), suggesting that DHT level is relatively higher than $\mathrm{E}_{2}$ level in each breast carcinoma tissue treated with exemestane. Moreover, intratumoral concentration of DHT was associated with that of testosterone in this study. DHT is locally produced from testosterone in human breast carcinoma tissues (Suzuki et al. 2007), and the intratumoral DHT level is considered to be mainly determined by amounts of the precursor testosterone (Mistry et al. 1986, Recchione et al. 1995). Aromatase catalyzes the conversion of androstenedione and testosterone to $\mathrm{E}_{1}$ and $\mathrm{E}_{2}$ respectively. Previously, Spinola et al. (1988) reported that treatment with an aromatase inhibitor (4-hydroxyandrostenedione) markedly elevated intratumoral testosterone concentrations in dimethylbenz(a)anthracene-induced rat mammary tumors, and Sonne-Hansen \& Lykkesfeldt (2005) showed that aromatase preferred testosterone as a substrate in MCF-7 breast carcinoma cells. Recently, Suzuki et al. (2007) have demonstrated that aromatase expression was inversely associated with intratumoral DHT concentrations in the breast carcinomas without neoadjuvant therapy, and aromatase suppressed DHT synthesis from androstenedione in the co-culture

Figure 4 Interaction of $E R$ and $A R$ functions in T-47D cells. (A and $B$ ) Effect of $E_{2}$ on DHT-dependent transactivation (A) or that of $\mathrm{DHT}$ on $\mathrm{E}_{2}$-dependent transactivation $(\mathrm{B})$ by luciferase analysis. T-47D cells were treated with indicated concentrations of $\mathrm{DHT}$ and $\mathrm{E}_{2}$ for $24 \mathrm{~h}$. Relative luciferase activity was evaluated as the ratio (\%) compared with the basal level (non-treatment). Data are presented as mean \pm s.D. $(n=3)$. ${ }^{\star} P<0.05$ and ${ }^{* * \star} P<0.001$ versus non-treatment (left column) respectively. The statistical analyses were performed using a one-way ANOVA and Bonferroni test. (C) Effects of $E_{2}$ on DHT-mediated $17 \beta H S D 2$ mRNA expression by real-time PCR analysis. T-47D cells were treated with DHT $(10 \mathrm{nM})$ and indicated concentrations of $\mathrm{E}_{2}$ for 3 days. Relative $17 \beta \mathrm{HSD} 2$ mRNA level was summarized as a ratio (\%) compared with the basal level (non-treatment). Data are presented as mean +s.D. $(n=3) .{ }^{* \star} P<0.01$ and ${ }^{* * *} P<0.001$ versus treatment with DHT alone (left column). (D) Scatter plot analysis of microarray data for the induced gene expression profile by $\mathrm{DHT}$ or $\mathrm{E}_{2}$. One thousand and twenty-nine genes, those that were more than 2.5 -fold induced by DHT $(10 \mathrm{nM})$ or $\mathrm{E}_{2}(10 \mathrm{nM})$ treatment for 3 days, were plotted on the logarithmic graph. Genes, those that were more than 2.0-fold higher in the DHT or $\mathrm{E}_{2}$ treatment, were located outside of the diagonal line, and classified as group $D$ or group E respectively. Genes $<2.0$-fold changes were plotted inside of these two lines, and classified as group $F$. The location of $17 \beta H S D 2$ was marked in this figure. (E) Effects of DHT on $\mathrm{E}_{2}$-mediated proliferation of T-47D cells by proliferation assay. T-47D cells were pretreated with or without DHT (10 nM) for 3 days, and then treated with $E_{2}(100 \mathrm{pM})$ with or without DHT $(10 \mathrm{nM})$ for 3 days. The number of the cells was evaluated as a ratio (\%) compared with that at day 0 after the treatment. The data are presented as gray bars and as mean \pm s.D. $(n=3)$.

Expression levels of $17 \beta H S D 2$ mRNA were also evaluated by real-time PCR analysis under the same condition, and represented as closed bars and as mean \pm s.D. $(n=3)$. ${ }^{\star} P<0.05,{ }^{\star \star} P<0.01$, and ${ }^{\star \star \star} P<0.001$ versus treatment with $\mathrm{E}_{2}$ alone (left column) respectively. 
experiments. Results of these studies all indicate that aromatase is a negative regulator of intratumoral DHT production in the breast carcinoma by mainly reducing concentration of the precursor testosterone. On the other hand, our present results showed that DHT:testosterone ratio in each patient, which suggests $5 \alpha$ Red activity, was at a similar level regardless of the exemestane therapy, and DHT did not change the $5 \alpha$ Redl mRNA level in T-47D cells. Therefore, neoadjuvant aromatase inhibitor therapy is considered to accompany additional effects through increasing local DHT concentration mainly by the inhibition of aromatase activity with estrogen deprivation.

Previous studies demonstrated that intratumoral $\mathrm{E}_{2}$ concentration was markedly suppressed in breast carcinoma tissues treated with non-steroidal aromatase inhibitors, such as anastrozole (89\% suppression for 15 weeks (Geisler et al. 2001)) and letrozole (98\% for 16 weeks (Geisler et al. 2006)). In our present study, intratumoral concentration of $\mathrm{E}_{2}$ in a group who received exemestane treatment for 2 weeks was $35 \%$ of that in a group without this mode of therapy (Fig. 1A). Although no data are currently available on the influence of steroidal aromatase inhibitor in intratumoral concentrations of $E_{2}$ to the best of our knowledge, results of our present study are in good agreement with the previous results of non-steroidal aromatase inhibitors. These results suggest that intratumoral $\mathrm{E}_{2}$ concentration is deprived in breast carcinoma tissues by aromatase inhibitors regardless of the types of inhibitors used. However, it is also true that change of the $\mathrm{E}_{2}$ concentration was not significant $(P=0.56)$ in this study, different from the DHT concentration $(P=0.01)$. It may be partly due to the fact that two separate sets of patients who were treated at two periods of times were used. However, considering that $\mathrm{E}_{2}$ is locally produced in the breast carcinoma tissue by several estrogen-producing enzymes such as aromatase, STS, and 17ßHSD1, while DHT is synthesized by $5 \alpha \operatorname{Red} 1$, it may be possible to speculate that STS and/or 17ßHSD1 interrupt the rapid decrement of $\mathrm{E}_{2}$ level in the breast carcinoma tissue treated with exemestane. It awaits further examinations.

In our present study, we demonstrated that $17 \beta$ HSD2 was induced by DHT in T-47D breast carcinoma cells, which was significantly inhibited by the addition of a potent AR blocker hydroxyflutamide (Fig. 3A). Several potential AREs were identified in the upstream region from -5 to $-7 \mathrm{kbp}$ of $17 \beta H S D 2$ gene using Transcription Element Search System (http://www.cbil.upenn.edu/cgi-bin/tess/tess), and Wang \& Tuohimaa (2007) reported an induction of
$17 \beta H S D 2$ mRNA expression by DHT in a prostate cancer cell line (LNCaP). Therefore, 17ßHSD2 is considered a DHT-induced gene in the breast carcinoma cells, although androgen-responsive genes are not currently characterized in the breast carcinoma, in contrast to the estrogen-induced genes. In our present study, exemestane directly caused androgen actions as a chemical in T-47D cells, including induction of $17 \beta$ HSD2 expression, and a great majority of exemestane-induced genes were overlapped with the DHT-induced genes (Fig. 3B and D; Table 4). Such findings have not been reported to the best of our knowledge, but these are considered reasonable because a steroidal aromatase inhibitor exemestane interferes with the substrate-binding sites of aromatase as an androgen analog (Miller \& Dixon 2002). Considering the fact that expression of $17 \beta H S D 2$ mRNA was not additively induced by DHT and exemestane (Fig. 3C), induction of 17ßHSD2 mRNA by these agents may be directly mediated by the same mechanisms through AR as an androgen or androgen analog. Therefore, 17ßHSD2 expression might be induced in a similar manner by other non-steroidal aromatase inhibitors through increasing the local DHT levels, but it awaits further investigations for clarification.

Previous in vitro studies demonstrated that DHT predominantly exerted anti-proliferative effects on mitogenic effects of estrogens in breast carcinoma cells (Poulin et al. 1988, Lapointe \& Labrie 2001), although some divergent or inconsistent findings have been reported in the literature (Ortmann et al. 2002, Somboonporn \& Davis 2004). This inhibitory effect was associated with an increment of a proportion of cells in $\mathrm{G}_{0} / \mathrm{G}_{1}$ phase or increased levels of p21 and/or p27 (Lapointe \& Labrie 2001, Greeve et al. 2004). In our present study, $\mathrm{E}_{2}$-mediated proliferation of T-47D cells was significantly inhibited by DHT, which was also associated with an increment of $17 \beta \mathrm{HSD} 2$ expression level (Fig. 4E). 17 $\beta \mathrm{HSD} 2$ catalyzes the oxidation of $\mathrm{E}_{2}$ to $\mathrm{E}_{1}$ (Wu et al. 1993), and intratumoral $\mathrm{E}_{2}$ concentration was inversely associated with $17 \beta$ HSD2 status in the breast carcinoma with exemestane in our present study (Table 2). Therefore, DHT is considered to inhibit an $\mathrm{E}_{2}$-mediated proliferation of breast carcinoma cells, at least in part, through decreasing local $\mathrm{E}_{2}$ concentration by $17 \beta \mathrm{HSD} 2$.

It is known that oxidative $17 \beta \mathrm{HSD} 2$ activity is a preferential direction in normal breast tissues (Miettinen et al. 1999), but the reductive 17ßHSD1 pathway has been reported to be dominant in actual human breast carcinoma tissues (Speirs et al. 1998, Miettinen et al. 1999). We previously reported 
Before aromatase inhibitor therapy

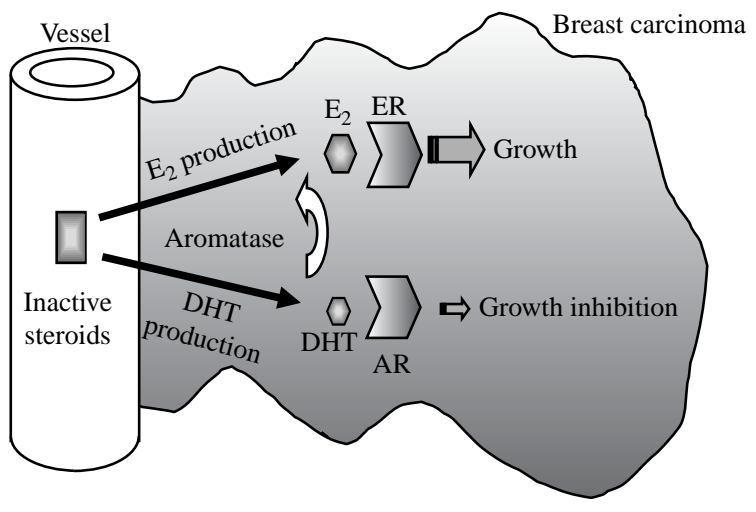

After aromatase inhibitor therapy

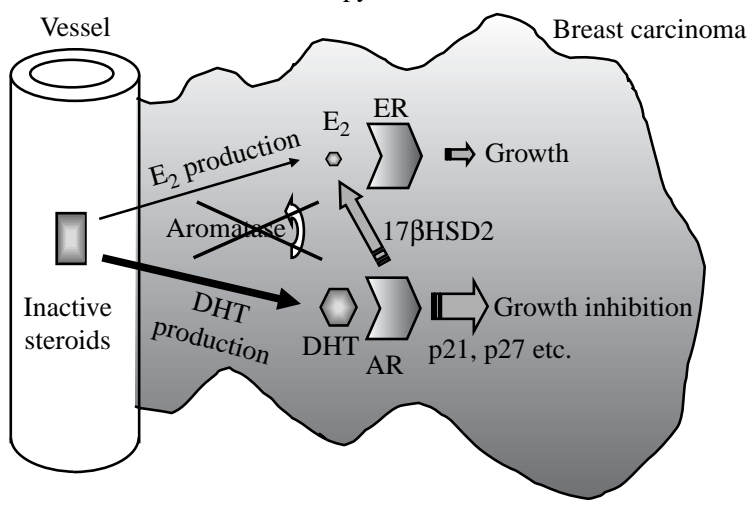

Figure 5 Scheme representing possible effects of aromatase inhibitor treatment on androgens in the breast carcinoma tissue, which is postulated from the results of our present study. DHT is locally produced in the breast carcinoma tissue, but its actions are possibly suppressed by predominant estrogen actions. The DHT level is increased in the breast carcinoma tissue by aromatase inhibitor treatment, causing induction of various DHT-induced genes. $17 \beta \mathrm{HSD} 2$ is identified as a DHT-induced gene in the breast carcinoma in this study, and it may be, at least in part, involved in the anti-proliferative effects of DHT by further decreasing intratumoral $\mathrm{E}_{2}$ concentration.

no $17 \beta$ HSD2 immunoreactivity in 111 breast carcinoma tissues examined (Suzuki et al. 2000), and Gunnarsson et al. (2001) also reported that $17 \beta H S D 2$ mRNA expression was detected only in 12 out of 84 (14\%) breast carcinomas. Recently, Han et al. (2008) have demonstrated that $17 \beta \mathrm{HSD} 2$ immunoreactivity was detected in 10 out of $50(20 \%)$ breast carcinomas, while its level of expression was $83 \%$ of the adjacent non-neoplastic mammary tissues. Although it might be partly due to the loss of heterozygosity of chromosome 16 in which $17 \beta H S D 2$ gene is located (Casey et al. 1994, Cleton-Jansen et al. 2001), it is unclear why $17 \beta$ HSD2 expression was so suppressed in human breast carcinoma.

Results of our present study demonstrated that AREdependent transactivation by DHT was markedly suppressed by $\mathrm{E}_{2}$ in $\mathrm{T}-47 \mathrm{D}$ cells (Fig. 4A), and DHT-mediated induction of $17 \beta \mathrm{HSD} 2$ expression was also inhibited by $E_{2}$ in a dose-dependent manner (Fig. 4C). Possible interaction of ER and AR functions was proposed by several groups. For instances, PanetRaymond et al. (2000) reported that coexpression of ER with AR decreased AR transactivation by $35 \%$, and demonstrated that both AR and ER can interact directly using the yeast and mammalian two-hybrid systems. In addition, Lanzino et al. (2005) showed that an AR-specific coactivator ARA70 also increased the ER transcriptional activity and modulated the functional ER/AR interplay in MCF-7 breast carcinoma cells. These results suggest that androgen actions are, in general, suppressed in breast carcinoma by predominant estrogen actions, even if the carcinoma cells expressed AR and intratumoral DHT reached a significant level. In addition, expression of an androgen-induced gene 17ßHSD2 may reflect intratumoral DHT actions in breast carcinoma more precisely than AR status. Gunnarsson et al. (2005) reported a significant association between $17 \beta H S D 2$ mRNA and better recurrence-free survival in the breast carcinoma. Therefore, 17 $\beta$ HSD2-positive breast carcinoma after a neoadjuvant aromatase inhibitor therapy possibly may grow more slowly by increased intratumoral DHT actions and/or further decreased estrogen actions by 17ßHSD2 (Fig. 5). Thus, 17ßHSD2 status may be a potent marker for response to neoadjuvant aromatase inhibitor therapy in the breast carcinoma, but it awaits further examinations to clarify the clinical significance of $17 \beta \mathrm{HSD} 2$ in the breast carcinoma.

In summary, intratumoral DHT concentration was significantly higher in the breast carcinomas treated with exemestane compared to those without the therapy, and 17ßHSD2 immunoreactivity was significantly increased by the treatment. Subsequent in vitro studies demonstrated that $17 \beta \mathrm{HSD} 2$ expression was induced by DHT in T-47D breast carcinoma cells in a dose-dependent manner, but the DHT-mediated induction was markedly suppressed by the addition of $E_{2}$. $E_{2}$-mediated cell proliferation was significantly inhibited by DHT in T-47D cells, which was also associated with an increment of the 17 $\beta$ HSD2 expression level. These results suggest that intratumoral DHT actions are increased during a neoadjuvant aromatase inhibitor therapy. $17 \beta H S D 2$ is identified as a potent DHT-induced gene in the breast carcinoma, and may be not only involved in the anti-proliferative effects of DHT on the breast carcinoma cells but also serve as a potential marker for response to a neoadjuvant aromatase inhibitor therapy in the breast carcinoma patient. 


\section{Declaration of interest}

The authors declare that there is no conflict of interest that could be perceived as prejudicing the impartiality of the research reported.

\section{Funding}

This work was partly supported by Grant-in-Aid for Scientific Research (19590339) from the Japanese Ministry of Education, Culture, Sports, Science, and Technology, and by educational grant from Pfizer Japan Inc (Tokyo, Japan).

\section{Acknowledgements}

We appreciate the skilful technical assistance of $\mathrm{Mr}$ Katsuhiko Ono and Ms Miki Mori (Department of Anatomic Pathology, Tohoku University Graduate School of Medicine, Sendai, Japan).

\section{References}

Adams JB, Pewnim T, Chandra DP, Archibald L \& Foo MS 1979 A correlation between estrogen sulfotransferase levels and estrogen receptor status in human primary breast carcinoma. Cancer Research 39 5124-5126.

Allred DC, Harvey JM, Berardo M \& Clark GM 1998 Prognostic and predictive factors in breast cancer by immunohistochemical analysis. Modern Pathology 11 155-168.

Baum M 2004 Current status of aromatase inhibitors in the management of breast cancer and critique of the NCIC MA-17 trial. Cancer Control 11 217-221.

Casey ML, MacDonald PC \& Andersson S 1994 17betaHydroxysteroid dehydrogenase type 2: chromosomal assignment and progestin regulation of gene expression in human endometrium. Journal of Clinical Investigation 94 2135-2141.

Cleton-Jansen AM, Callen DF, Seshadri R, Goldup S, Mccallum B, Crawford J, Powell JA, Settasatian C, van Beerendonk H, Moerland EW et al. 2001 Loss of heterozygosity mapping at chromosome arm 16q in 712 breast tumors reveals factors that influence delineation of candidate regions. Cancer Research 61 1171-1177.

Coombes RC, Hall E, Gibson LJ, Paridaens R, Jassem J, Delozier T, Jones SE, Alvarez I, Bertelli G, Ortmann O et al. 2004 A randomized trial of exemestane after two to three years of tamoxifen therapy in postmenopausal women with primary breast cancer. New England Journal of Medicine 350 1081-1092.

Dowsett M, Ebbs SR, Dixon JM, Skene A, Griffith C, Boeddinghaus I, Salter J, Detre S, Hills M, Ashley S et al. $2005 a$ Biomarker changes during neoadjuvant anastrozole, tamoxifen, or the combination: influence of hormonal status and HER-2 in breast cancer - a study from the IMPACT trialists. Journal of Clinical Oncology 23 2477-2492.
Dowsett M, Smith IE, Ebbs SR, Dixon JM, Skene A, Griffith C, Boeddinghaus I, Salter J, Detre S, Hills M et al. 2005 b Short-term changes in Ki-67 during neoadjuvant treatment of primary breast cancer with anastrozole or tamoxifen alone or combined correlate with recurrencefree survival. Clinical Cancer Research 11 951s-958s.

Ellis MJ, Coop A, Singh B, Tao Y, Llombart-Cussac A, Jänicke F, Mauriac L, Quebe-Fehling E, Chaudri-Ross HA, Evans DB et al. 2003 Letrozole inhibits tumor proliferation more effectively than tamoxifen independent of HER1/2 expression status. Cancer Research 63 6523-6531.

Evans TR, Rowlands MG, Law M \& Coombes RC 1994 Intratumoral oestrone sulphatase activity as a prognostic marker in human breast carcinoma. British Journal of Cancer $69555-561$.

Geisler J, Detre S, Berntsen H, Ottestad L, Lindtjørn B, Dowsett M \& Einstein Lønning P 2001 Influence of neoadjuvant anastrozole (Arimidex) on intratumoral estrogen levels and proliferation markers in patients with locally advanced breast cancer. Clinical Cancer Research 7 1230-1236.

Geisler J, Helle H, Ekse D, Duong NK, Evans D \& Lønning PE 2006 Letrozole (Femara) causes potent suppression of breast cancer tissue estrogen levels in the neoadjuvant setting. Journal of Clinical Oncology Supplement 2410532.

Goss PE, Ingle JN, Martino S, Robert NJ, Muss HB, Piccart MJ, Castiglione M, Tu D, Shepherd LE, Pritchard KI et al. 2003 A randomized trial of letrozole in postmenopausal women after five years of tamoxifen therapy for early-stage breast cancer. New England Journal of Medicine 349 1793-1802.

Greeve MA, Allan RK, Harvey JM \& Bentel JM 2004 Inhibition of MCF-7 breast cancer cell proliferation by 5alpha-dihydrotestosterone; a role for p21(Cip1/Waf1). Journal of Molecular Endocrinology 32 793-810.

Gunnarsson C, Olsson BM \& Stål O 2001 Abnormal expression of 17beta-hydroxysteroid dehydrogenases in breast cancer predicts late recurrence. Cancer Research 61 8448-8451.

Gunnarsson C, Hellqvist E \& Stål O 2005 17betaHydroxysteroid dehydrogenases involved in local oestrogen synthesis have prognostic significance in breast cancer. British Journal of Cancer 92 547-552.

Han B, Li S, Song D, Poisson-Paré D, Liu G, Luu-The V, Ouellet J, Li S, Labrie F \& Pelletier G 2008 Expression of 17beta-hydroxysteroid dehydrogenase type 2 and type 5 in breast cancer and adjacent non-malignant tissue: a correlation to clinicopathological parameters. Journal of Steroid Biochemistry and Molecular Biology 112 194-200.

Howell A, Cuzick J, Baum M, Buzdar A, Dowsett M, Forbes JF, Hoctin-Boes G, Houghton J, Locker GY \& Tobias JS 2005 Results of the ATAC (Arimidex, Tamoxifen, Alone or in Combination) trial after completion of 5 years' adjuvant treatment for breast cancer. Lancet 365 60-62. 
Kannan K, Amariglio N, Rechavi G, Jakob-Hirsch J, Kela I, Kaminski N, Getz G, Domany E \& Givol D 2001 DNA microarrays identification of primary and secondary target genes regulated by p53. Oncogene 20 2225-2234.

Lanzino M, De Amicis F, McPhaul MJ, Marsico S, Panno ML \& Andò S 2005 Endogenous coactivator ARA70 interacts with estrogen receptor alpha (ERalpha) and modulates the functional ERalpha/androgen receptor interplay in MCF-7 cells. Journal of Biological Chemistry 280 20421-20430.

Lapointe J \& Labrie C 2001 Role of the cyclin-dependent kinase inhibitor p27(Kip1) in androgen-induced inhibition of CAMA-1 breast cancer cell proliferation. Endocrinology 142 4331-4338.

Lee YF, Lin WJ, Huang J, Messing EM, Chan FL, Wilding G \& Chang C 2002 Activation of mitogen-activated protein kinase pathway by the antiandrogen hydroxyflutamide in androgen receptor-negative prostate cancer cells. Cancer Research 62 6039-6044.

Miettinen M, Mustonen M, Poutanen M, Isomaa V, Wickman M, Söderqvist G, Vihko R \& Vihko P 1999 17betaHydroxysteroid dehydrogenases in normal human mammary epithelial cells and breast tissue. Breast Cancer Research and Treatment 57 175-182.

Migliaccio A, Castoria G, Di Domenico M, de Falco A, Bilancio A, Lombardi M, Barone MV, Ametrano D, Zannini MS, Abbondanza C et al. 2000 Steroid-induced androgen receptor-oestradiol receptor beta-Src complex triggers prostate cancer cell proliferation. EMBO Journal 19 5406-5417.

Miki Y, Suzuki T, Tazawa C, Yamaguchi Y, Kitada K, Honma S, Moriya T, Hirakawa H, Evans DB, Hayashi S et al. 2007 Aromatase localization in human breast cancer tissues: possible interactions between intratumoral stromal and parenchymal cells. Cancer Research 67 3945-3954.

Miller WR \& Dixon JM 2002 Endocrine and clinical endpoints of exemestane as neoadjuvant therapy. Cancer Control 9 9-15.

Mistry P, Griffiths K \& Maynard PV 1986 Endogenous C19-steroids and oestradiol levels in human primary breast tumour tissues and their correlation with androgen and oestrogen receptors. Journal of Steroid Biochemistry 24 1117-1125.

Olson JA Jr, Budd GT, Carey LA, Harris LA, Esserman LJ, Fleming GF, Marcom PK, Leight GS Jr, Giuntoli T, Commean P et al. 2009 Improved surgical outcomes for breast cancer patients receiving neoadjuvant aromatase inhibitor therapy: results from a multicenter phase II trial. Journal of the American College of Surgeons 208 906-914.

Ortmann J, Prifti S, Bohlmann MK, Rehberger-Schneider S, Strowitzki T \& Rabe T 2002 Testosterone and 5alphadihydrotestosterone inhibit in vitro growth of human breast cancer cell lines. Gynecological Endocrinology 16 113-120.
Panet-Raymond V, Gottlieb B, Beitel LK, Pinsky L \& Trifiro MA 2000 Interactions between androgen and estrogen receptors and the effects on their transactivational properties. Molecular and Cellular Endocrinology 167 139-150.

Penning TM, Steckelbroeck S, Bauman DR, Miller MW, Jin Y, Peehl DM, Fung KM \& Lin HK 2006 Aldo-keto reductase $(\mathrm{AKR}) 1 \mathrm{C} 3$ : role in prostate disease and the development of specific inhibitors. Molecular and Cellular Endocrinology 248 182-191.

Poulin R, Baker D \& Labrie F 1988 Androgens inhibit basal and estrogen-induced cell proliferation in the ZR-75-1 human breast cancer cell line. Breast Cancer Research and Treatment 12 213-225.

Recchione C, Venturelli E, Manzari A, Cavalleri A, Martinetti A \& Secreto G 1995 Testosterone, dihydrotestosterone and oestradiol levels in postmenopausal breast cancer tissues. Journal of Steroid Biochemistry and Molecular Biology 52 541-546.

Saji S, Okumura N, Eguchi H, Nakashima S, Suzuki A, Toi M, Nozawa Y, Saji S \& Hayashi S 2001 MDM2 enhances the function of estrogen receptor alpha in human breast cancer cells. Biochemical and Biophysical Research Communications 281 259-265.

Sakamoto T, Eguchi H, Omoto Y, Ayabe T, Mori H \& Hayashi S 2002 Estrogen receptor-mediated effects of tamoxifen on human endometrial cancer cells. Molecular and Cellular Endocrinology 192 93-104.

Shibuya R, Suzuki T, Miki Y, Yoshida K, Moriya T, Ono K, Akahira J, Ishida T, Hirakawa H, Evans DB et al. 2008 Intratumoral concentration of sex steroids and expression of sex steroid-producing enzymes in ductal carcinoma in situ of human breast. Endocrine-Related Cancer 15 113-124.

Silva MC, Rowlands MG, Dowsett M, Gusterson B, McKinna JA, Fryatt I \& Coombes RC 1989 Intratumoral aromatase as a prognostic factor in human breast carcinoma. Cancer Research 49 2588-2591.

Somboonporn W \& Davis SR 2004 Postmenopausal testosterone therapy and breast cancer risk. Maturitas 49 267-275.

Sonne-Hansen K \& Lykkesfeldt AE 2005 Endogenous aromatization of testosterone results in growth stimulation of the human MCF-7 breast cancer cell line.

Journal of Steroid Biochemistry and Molecular Biology 93 25-34.

Speirs V, Green AR, Walton DS, Kerin MJ, Fox JN, Carleton PJ, Desai SB \& Atkin SL 1998 Short-term primary culture of epithelial cells derived from human breast tumours. British Journal of Cancer 78 1421-1429.

Spinola PG, Marchetti B, Mérand Y, Bélanger A \& Labrie F 1988 Effects of the aromatase inhibitor 4-hydroxyandrostenedione and the antiandrogen flutamide on growth and steroid levels in DMBA-induced rat mammary tumors. Breast Cancer Research and Treatment 12 287-296. 
Suzuki T, Moriya T, Ariga N, Kaneko C, Kanazawa M \& Sasano H 2000 17beta-Hydroxysteroid dehydrogenase type 1 and type 2 in human breast carcinoma: a correlation to clinicopathological parameters. British Journal of Cancer 82 518-523.

Suzuki T, Darnel AD, Akahira JI, Ariga N, Ogawa S, Kaneko C, Takeyama J, Moriya T \& Sasano H 2001 5alpha-Reductases in human breast carcinoma: possible modulator of in situ androgenic actions. Journal of Clinical Endocrinology and Metabolism 86 2250-2257.

Suzuki T, Miki Y, Nakata T, Shiotsu Y, Akinaga S, Inoue K, Ishida T, Kimura M, Moriya T \& Sasano H 2003 Steroid sulfatase and estrogen sulfotransferase in normal human tissue and breast carcinoma.

Journal of Steroid Biochemistry and Molecular Biology 86 449-454.

Suzuki T, Miki Y, Moriya T, Akahira J, Ishida T, Hirakawa H, Yamaguchi Y, Hayashi S \& Sasano H 2007 5alpha-Reductase type 1 and aromatase in breast carcinoma as regulators of in situ androgen production. International Journal of Cancer $\mathbf{1 2 0}$ 285-291.

Wang JH \& Tuohimaa P 2007 Regulation of 17betahydroxysteroid dehydrogenase type 2 , type 4 and type 5 by calcitriol, LXR agonist and 5alpha-dihydrotestosterone in human prostate cancer cells. Journal of Steroid Biochemistry and Molecular Biology 107 100-105.

Wu L, Einstein M, Geissler WM, Chan HK, Elliston KO \& Andersson S 1993 Expression cloning and characterization of human 17 beta-hydroxysteroid dehydrogenase type 2, a microsomal enzyme possessing 20 alphahydroxysteroid dehydrogenase activity. Journal of Biological Chemistry 268 12964-12969.

Yamashita K, Okuyama M, Watanabe Y, Honma S, Kobayashi S \& Numazawa M 2007 Highly sensitive determination of estrone and estradiol in human serum by liquid chromatography-electrospray ionization tandem mass spectrometry. Steroids 72 819-827. 